\title{
Three-Dimensional Brand Loyalty and Virtual Customer Relationships on Social Media-Based Brand Community
}

\author{
Ayesha Sharif, Zuraidah Binti Sulaiman
}

\begin{abstract}
The aim of this research was to investigate how to manage digital consumer relationships (i.e. Customer-centric model) on social media brand community and to influence three-dimensional brand loyalty (i.e. cognitive, affective, and behavioral loyalty). This study depicts how different factors and building blocks of these online brand communities interact and influence brand community participation, and brand loyalty. The results of this research indicated that all these four consumer relationships can enhance brand loyalty by improving brand community participation. The finding will help marketers and brands may make marketing plans to influence any kind of unsatisfactory situations. This study is one of the first to investigates how to manage consumer relationships on social media through brand community participation.

Index Terms: Social media. Brand community, brand community participation, brand loyalty, a customer-centric model of brand community
\end{abstract}

\section{INTRODUCTION}

In the advanced competitions, brands are a focus on their value for the purpose of achieving tremendous profits [1] and social media play an important role to increase brand value. Social media have infiltrated and evolved into an essential part of the lives of trillions of individuals who are the users of the internet [2]. In the last decade, the idea of brand communities in social media captures an important area in the research of the electronic market. Specifically, with the recognition and development in social media, the operating social media brand communities have evolved into a huge fashionable and may be indicated as a network of relatives for professional and social engagements now [3]. In social media brand communities, where customers may come together, is very quickly enhancing, and customers are managed by mutual goals to connect with similar users' thoughts and explore to enhance brand loyalty and longrunning relation with the customer. In the last decade, the idea of brand communities in social media captures an important area in the research of the electronic market.

\section{Revised Manuscript Received on November 19, 2019}

Ayesha Sharif, Faculty of Azman Hashim International Business School (AHIBS), Universiti Teknologi Malaysia (UTM), 81310 Johor Bahru, Johor, Malaysia, ayeshasharif@yahoo.com

Zuraidah Binti Sulaiman, Faculty of Azman Hashim International Business School (AHIBS), Universiti Teknologi Malaysia (UTM), 81310 Johor Bahru, Johor, Malaysia.
Specifically, with the recognition and development in social media, the operating SMBCs have evolved into a huge fashionable and may be indicated as a network of relatives for professional and social engagements now [3]. Social network sites are a device that helps both viral marketing and electronic commerce and allow the process of making relations to a network and around society [4]. Recently, about 90 percent of Asian brand is using social media as a podium of electronic commerce, and 75 percent of these brands have developed policy in social media [5]. In the last decade, the idea of brand communities in social media captures an important area in the research of the electronic market. Specifically, with the recognition and development in social media, the operating SMBCs have evolved into a huge fashionable and may be indicated as a network of relatives for professional and social engagements now [3]. Most of the researchers have observed the social impact of social media brand communities and also concerned in terms of learning about, managing, and promoting, like a [6]. Many researches determine this condition, including the capability of social media brand communities to impact on user's perception and behaviours such as [7] to briskly distribute knowledge [8], to relate and participate with highly loyal consumers for example [9] and to connect in activities of communities [10]. Social network sites are a device that helps both viral marketing and electronic commerce and allow the process of making relations to a network and around society [4]. Recently, about 90 percent of the Asian brand is using social media as a podium of electronic commerce, and 75 percent of these brands have developed policy in social media [5]. Past studies have shown that the brand community consists of UGC, marketer generated content, its entities (Marketers, consumers, platforms) and the consumer's relationship (customer-centric model) with these entities [11]. Thus, these consumer relationships with other entities and information comprise are important to the brand community [12]. Despite its importance, limited studies were done in the area of SMBC (Habibi et al. 2014a). the current information of $\mathrm{OBC}$ does not fit with the new aspects of SMBC in which the structure of the communities, the social perspective within which users communicate, the way stories and the size, are being told are different from prior types of brand communities. This study makes important 


\section{Three-Dimensional Brand Loyalty and Virtual Customer Relationships on Social Media-Based Brand Community}

contributions by filling this void.Companies and brands are focus on one question that is how to build strong brand loyalty through social media.

It is the biggest challenge for marketers and organizational professionals and the hottest research topic for researchers. It also creates a high complexity in the concept of operationalization and brand loyalty. While loyalty is directly related to the positive behaviour of the customer towards the brand and users of the product want to share their experience with their friends [13]. Today in the age of advanced technology, the internet is now spreading in the world very fast as compared in the past, due to this the competition among the brands is more severe to survive. In a digitally and globalized connected world of business where various firms and brands are available to consumers, it has become tough for companies and marketers to retain consumers and create loyal consumers. Therefore, brand loyalty is an important issue and a central part of the marketing plan of any company and brand [14, 15]. According to [16], brand community based on social media provide two-way communication, which facilitates brands to receive consumer's response regarding their expectations of services and products efficiently, allowing customers to respond to, and fulfill/satisfy their needs. Satisfied consumers are not only loyal to a specific brand, but they also continual buyers to the specific brand's product and are happy to share or promote these products to their relatives. In the recent years, both the growing popularity of social network sites, and the competitors, existence on social media and the cost-cutting pressure, obtained from the financial trouble and consequent need to search economical solutions for company promotion, motivated brands to use social network sites as part of their brand building and marketing activities [17, 18].on the order side, brand loyalty is tough to develop because of increasing competition, it has become one of the important challenges for brand marketers in the last two decade [15]. Moreover, brand loyalty is all human behaviour which is a mixture of three different types of reactions: Cognitive reactions (I think) second is affective reactions (I feel), and third is Behavioural reactions (I do). Brand loyalty three-dimensional method states an also fine-grained method which may be applied to determine the areas of weakness and strength. Unlike prior loyalty studies, we broaden the loyalty perspective, conceptualizing and measuring cognitive loyalty, affective loyalty, and behavioural, elements of loyalty. Many prior researches in consumer behaviour and in marketing have pointed out that the cognitive phase of loyalty mainly contains perceived value including psychological/functional factors and quality [19-21], [22]. This can be described as a consumer's bond with the brand depend on the gathering of pleasing experiences $[23,24]$. This stage of loyalty is distinct from the rest since it includes a customer's emotional attachment. In this phase, however, customers may also convert to another brand product even if this relation exists [25] for e.g. if the other company offers unexpectedly a lower price [25]. Behavioural loyalty is the third stage in which customer has the aim to rebuy rather than the cognitive or affective loyalty [19] because behavioural loyalty component can expand from each of two cognitive or affective components of loyalty $[21,26]$.

The internet has huge transformation which generates different significant of brand communities which is different from offline or face to face brand communities. SMBCs have the same features as that of the internet such as a multi-party interaction, geographical restriction, time, etc. [27]. In addition, social media increasing fostered as a new media communication channel-related with the proposition of customers' participation as an important trigger to create positive brand outcomes [17]. Past studies on brand communities have determined the value of the consumer's participation in the survival of a brand community $[28,29]$. Past brand community participation literature demonstrated that allowing a greater level of customer participation advantages for consumers through better quality, personalize brand knowledge, which enables consumers to have extra power over their brand knowledge and powerfully related relation [30].

\section{CONCEPTUAL FRAMEWORK BASED ON THEORETICAL FOUNDATION}

RM is being applied which, without any confusion is being considered as an area of developing interest among the marketers. It is being applied by companies all over the world for creating successful relationships with consumers [31]. In the era of market turbulence and global competition, the need for RM can't be underestimated. To remain competitive, companies identify the importance of developing and maintaining, retaining relationships with their consumers [32]. When relationship marketing first developed, some scholars considered it as a new fad [33, 34]. [35] was a first in describing the term "relationship marketing". [35] examined relationship marketing (RM) as a strategy to maintain, enhance, and attract consumer relationships. Furthermore, marketing relationships may be copied back to old trade relationships, RM only developed into a separate area of marketing study during the 1990s [36]. At the same time, try to describe RM has multiplied, the aim of achieving conceptual contents remains tricky though [37]. That said, few features of RM are found to be repeating in most definitions involving retention, acquisition, a long-run orientation, a win-win situation and profitability enhancement for all stakeholders of the firm [37]. As part of this progress, RM also appeared as a key study topic within the literature of service marketing [38] and is among the extremely cited topics (Roberts et al. 2014). Since the early 1980 s, scholars have projected that RM includes "establishing" [39] and "attracting" [40] relationships while more developing, maintaining, enhancing and retaining relationships. However, RM is not more than just getting the consumers, but it is more how to retain, maintain the existing consumers as much as possible. There are essential elements that supported the strength of RM that can lead to brand loyalty [41]. In relation, brand loyalty mention as a favorable outcome towards a brand additionally to purchasing it repeatedly 
by the consumer. The consumer tends to be loyal since there is RM between them and the firm. Studies have shown that the amount of serving one loyal consumer is five to six timeless than the amount of serving and attracting one new consumer.

For marketers and scholars, through RM or developing relationships, to improve customer loyalty has been an essential issue [42]. Although there is a huge list of advantages related to RM, the limit is understood from an empirical perspective about the (indirect or direct) impact on elements of RM on consumer loyalty as vast scholarship in this field has remained conceptual [43]. Many researches on RM have sought to associate the outcome to consumer loyalty [44, 45]. Berry and Parasuraman (1991) stated that the first stage of RM depends on pricing incentives to protect consumer loyalty such as financial bonds. In the same vein, [46] has content that maintaining and developing consumer loyalty based on RM has become essential for business strategy.

\section{A. Social media brand communities}

A social media-based brand community is made up of two important concepts, social media and brand community. Social media are defined as platform for online applications, which facilitates user's interaction with one another, allows them to collaborate and share contents with their own network and brand community is defined as a non-geographic bound, structural social relations among the members of community of that brand who are the consumers of that brand of goods or services [47]. However, marketers and brand ambassadors have faced a new challenge or opportunity to regard brand communities, after all, it provides a new platform for customer/brand connection [48-50]. Social media is the best place for the purpose of development of brand communities. Anyhow in the few past researches conducted on the advantages and the effects of social media brand communities. In previous studies [51] described the customer's relationship with social media brand community elements with a customer-centric model that effect on brand trust. However, the brand community interpretation is an exclusive relationship among the brand to consumers, company to consumer, consumer to product and other customers of the brand [6]. Brand communities on social media are building and managing an online world it is not restricted by geographically nowadays [52]. These brand communities established modern marketing analysis methods, after all, researchers may intake trustworthy knowledge regard customers who are and acquired awareness of different phases of their life on every day such as their demands, requirements, dreams, behaviour, and devouring assumptions [53-57]. On the other side, the evaluation of social networking sites, under whose brolly social media such as a Facebook drop, has to define again the idea of the spread of marketing information due to the developing media climate that they created [58].Today customers may search other customers who have the same thoughts, beliefs, and goals in this world. This concept goes closely associated with the basic activity of social network sites, in which customers can communicate in real-time conversions. Social media which are also called a social network service, are podiums in which customers can create their private communal system of connections and create affiliation through public profiles or arranging friend's lists. Social media are based on websites which allow consumers to connect with mobile, share information through the multimedia and personal website. Currently, social media is declared the most superior from 2016 to 2018 in the field of research and get much more preference [59]. The brand community can be defined as a customer's bring together in an online platform, to search common values, beliefs, thoughts which evolve through the community. Many companies or brands have apparent their online existence through the brand communities in recent year, helping to consumers to understand their aims which related to the brand and also communicate with their consumers in a certain time [60]. According to the [61], integration of brand community is comprised of consumer relationship (brand community elements) with other entities such as a consumer-brand, consumer-marketers, consumer-company, and consumer to other consumers. In order to understand how to maintain and manage a good relationship within a bra and community, a customer-centric model of brand community [6] is applied in this research. This research is going to investigate individual digital customer relationships within SMBC by exploring these four relationships.

\section{B. Brand community participation}

In a study conducted by [12], it is observed that Consumer' participation is very important to the survival of the online brand community and brand community elements (four kinds of consumer relationships), information quality has been shown a positive impact on consumer participation through a perceived flow. Participation is specifically valuable for such brand communities due to favourable outcomes and durability [62]. According to [63] the success of a brand community is mirrored by the different levels of participation by its users. Additionally, successful participation is likely to outcome in more user-generated content on the website, or which would perform on the website as an attraction for first-time viewers to explore this. However, the customer is a maker of a brand community and it is also made for consumers [64] with the active participating they have felt the connection with the brand, community, and other community members $[47,65,66]$. Thus, some researchers, Such as a [67] and [68] supposed that community participation has evolved into essential to be recognized. Furthermore, Members like to participate in the brand community since they may acquire beneficial knowledge [69] create productive connections through interaction with other users participants with a brand community [70-73] and feel honoured via collective acts as a helper to other members $[69,70]$. The biggest challenge has faced by brands in social media is to 


\section{Three-Dimensional Brand Loyalty and Virtual Customer Relationships on Social Media-Based Brand Community}

confirm that a customer participates in their online brand community. Participation is specifically valuable for such brand communities due to favourable outcomes and durability [62]. It also contributes to gain new customers and build a powerful relationship between remaining ones [74] and promote with the compliments of objectives by both its members or brand and also promoting the community [75]. Participation normally directs to taking part in activities. In brand community participation users participates in different activities to share experience, information, or emotions which are associated with mutual interest. Despite this growing popularity and the common agreement on the effect of consumer's participation to a SMBC, a systematic understanding by brand scholars and managers on how to promote the consumer's participation remains elusive [12]. To address these issues, the current research proposes a conceptual model that discusses how the customer relationships (customer-centric model) influence each other through the consumer's participation which leads to brand loyalty.

\section{Brand loyalty}

Brand loyalty is the central point of attraction for marketer's practitioners and scholars [76]. Recently, it is an idea that has created much attraction, with many firms seeking to build brand loyalty from their customers [77]. Brand loyalty is "Positive feelings towards the brand and intense dedication to purchase the same product/service repeatedly now and in the future from the same brand, regardless of competitors' actions" [78]. According to [24], brand loyalty is a feeling like a strongly obligated to repurchase to a favourite product constantly in the future, that in spite of all circumstantial effects and other company's attractive appeals for converting an action but a particular person re-purchase same product from the same brand. While, brand loyalty has been applied by marketers as a critical powerful tool to present a continual competitive benefit [79, 80]. Additionally,[81] argued that the amount of appealing new consumers has been establishing to be up to 6 times greater than the amount of maintaining old ones. It is further that, loyal consumers are usually less price-conscious [82] or the existence of a loyal consumer base gives the company with important time to answers the competitive deed [83]. According to [84] brand loyalty is thus identified as one of the very important matters in the literature of marketing. Brand loyalty is tough to develop because of increasing competition, it has become one of the important challenges for brand marketers in the last two decades [15]. [85, 86] defined brand loyalty as an obligation of consumers against the brand with the repeat purchase behaviours in the future. Brand loyalty is the power of the company collected additional between the good relationships with customer and name identification [87], which influence to boost earning and greater gain toward challenging brands [88] In past researches, brand loyalty has been defined with two types: Attitudinal loyalty or behavioural loyalty [89-93]. On the other hand, [94] described a concept of loyalty in which they introduce two elements that influence loyalty such as cognitive or emotional loyalty. Many types of research have focused on distinct levels of loyalty base on nature, although some researchers have attracted on the personal aspects of the method [95]. Using a three-dimensional method, brand loyalty is consequently a mixture of a customer's feelings and thoughts about a specific brand that is then shown as an action. Along, according to [96] all human behaviour is blended with cognitive, affective, and behavioural reactions. When two-dimensional concepts come together with behavioural loyalty it becomes a three-dimensional approach of brand loyalty [95].

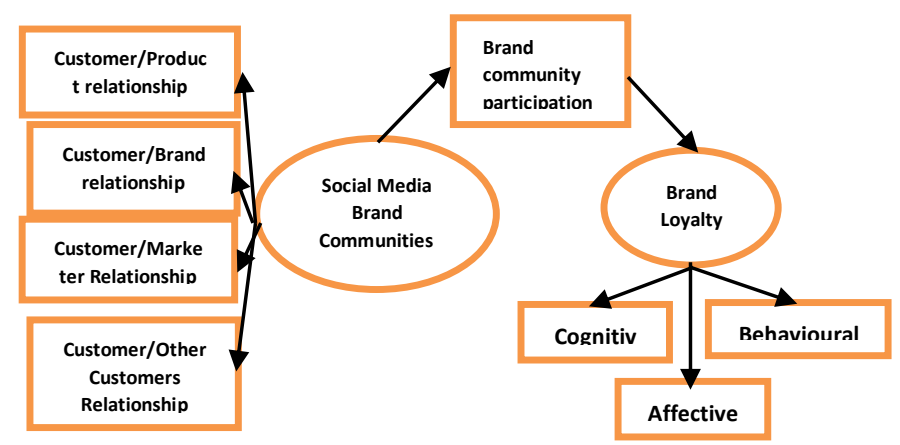

Theoretical Frameworks of SMBCs

\section{DEVELOPMENT OF HYPOTHESIS IN RELATIONS TO THE CONCEPTUAL FRAMEWORK \\ A. Social Media Brand Community \& Brand loyalty}

Social media is beneficially helping to brand for making strong brand communities. For the marketers the idea of brand community is most important because brands have known that loyal consumers are important assets of the company, who are the sign of success are interacting in brand communities and brand's favourite outcomes are depend on loyal customer, it is too hard to search new customers constantly without creating any struggle to maintain and retain ongoing consumes [97]. [50] have shown that brand community refers to particular brand loyalty and brand trust. In his research, it was observed that SMBC elements (i.e. Product, brand, company, and another customer) effects brand and consumer relationships. The social media brand communities are the best platform for the brand loyalty program and at the same time its work on the level of loyalty directly [98]. Nowadays companies and marketers have lots of attraction and curiosity in SMBCs due to boost brand loyalty of their users [99]. In the literature, Researchers have provided few analytical understanding of brand loyalty in the field of social media brand communities [100]. Moreover, [101] investigated that the impact of four structuring elements of social media brand community such as a customer's connection with the product, marketer, brand and other customers on brand community identification and brand loyalty. It was found that these dimensions may positively enhance brand loyalty. Considering the preceding the hypothesis is 
H1: Social media brand community will be positively significant related to brand loyalty.

\section{B. Social Media Brand Community \& Brand community participation}

[102] describe that marketers have a various alternative for brands within social media. They may use not only paid showing advertising, issue brand-related subject matter in social network sites, participate in social media, but also marketers may grow branded obligation convenience for consumer participation within social network sites. While participation (offering, formation, and consumption), consumers will be capable to understand the brand in the better way, to adopt their projection, and to have a powerful understanding of cost minimizes and customization.

[103-105] have found that if the users come to be psychologically connected to the brand community, they also pretend to behave in terms of their brand community worth's. Customer participation in the brand community is a sign of their achievement with the brand community and it is an important element for the promotion of aims of the community [106]. Considering the preceding the hypothesis is H2: Social media brand community will be significant to positively affect brand community participation

\section{Brand community participation \& Brand loyalty}

According to $[10,62]$ participation in the brand community lead to brand loyalty, knowledge of the brand, or WOM. Thus, participation has given favour to enhance the movement to stay within the brand community, to remain certain suggestions about the brand and to better the information about the brand [107]. The user's participation in a virtual brand community is an important factor to ensure the community's viability in the long run [108]. Customer participation is to increase satisfaction and loyalty positively in the context of co-creation [109]. [10] supposed that powerful participation in the brand community leads to a long run connection. In the study of [110] has shown that a user's active participation positively affects directly to brand loyalty. Considering the preceding the hypothesis is

H3: Brand community participation will be significant to positively affect brand loyalty

\section{Mediating effect of Brand community participation between Social Media Brand Community \& Brand loyalty}

The results of participation are normally to be considered about loyalty from prior researches, such as [84] declared that participation in essential for the brand community to enhances customers' loyalty. Customers who are come to be a member of the brand communities in social media favour to be loyal and devoted to the brand and are also open to receiving knowledge about the brand or company [75]. In the study of [111] has investigated the impact of customers' lurking or posting behaviours in virtual online communities on brand loyalty. Considering the preceding the hypothesis is
H4: Brand community participation will mediate the relationship between social media brand communities and brand loyalty

\section{CONCLUSION AND RECOMMENDATION FOR FUTURE RESEARCH}

While this present research does have multiple implications, it is also bound to certain limitations. The research will highlight the importance of social media as a tool for the development of brand loyalty. This study applied a cross-sectional research design. This is due to the time constraint to gather data. In future longitudinal studies could enable researchers to create more insight into the dynamic interactions among the brand community elements. Prior literature highlighted various brand loyalty determinants. And another limitation in this study considers only brand loyalty three-dimensional approach as an outcome; it will be more beneficial if this study can also evaluate other outcomes, such as brand evangelism, WOM, etc.

\section{REFERENCES}

1. Chaudhry, A.A. and S.A.L. Ramakrishnan, Corporate social responsibility, brand equity, and shareholder value: Theoretical and conceptual perspectives. International Journal of Recent Technology and Engineering, 2019. 8(2 Special Issue 9): p. 22-31.

2. Bronstein, J., Like me! Analyzing the 2012 presidential candidates' Facebook pages. Online Information Review, 2013. 37(2): p. 173192

3. Trusov, M., R.E. Bucklin, and K. Pauwels, Effects of word-of-mouth versus traditional marketing: findings from an internet social networking site. Journal of marketing, 2009. 73(5): p. 90-102.

4. Zarrella, D., The social media marketing book. 2009: " O'Reilly Media, Inc.".

5. Pon, Y. and C. Wang, Which keyword let brand control the digital trend? Brand News. 2012.

6. McAlexander, J.H., J.W. Schouten, and H.F. Koenig, Building brand community. Journal of marketing, 2002. 66(1): p. 38-54.

7. Muniz Jr, A.M. and H.J. Schau, Religiosity in the abandoned Apple Newton brand community. Journal of consumer research, 2005. 31(4): p. 737-747.

8. Brown, S., R.V. Kozinets, and J.F. Sherry Jr, Teaching old brands new tricks: Retro branding and the revival of brand meaning. Journal of Marketing, 2003. 67(3): p. 19-33.

9. Franke, N. and S. Shah, How communities support innovative activities: an exploration of assistance and sharing among endusers. Research policy, 2003. 32(1): p. 157-178.

10. Algesheimer, R., U.M. Dholakia, and A. Herrmann, The social influence of brand community: Evidence from European car clubs. Journal of marketing, 2005. 69(3): p. 19-34.

11. Goh, K.-Y., C.-S. Heng, and Z. Lin, Social media brand community and consumer behavior: Quantifying the relative impact of user-and marketer-generated content. Information Systems Research, 2013. 24(1): p. 88-107.

12. Zhao, H., Information Quality or Entities' Interactivity? Understanding the Determinants of Social Network-Based Brand Community Participation. Future Internet, 2019. 11(4): p. 87.

13. Watson, G.F., et al., Building, measuring, and profiting from customer loyalty. Journal of the Academy of Marketing Science, 2015. 43(6): p. 790-825.

14. Somro, Y.A. and M.A. Issani, SUCCESS OF BRAND EXTENSION IN GLOCALIZATION: A MEDIATION AND MODERATION ANALYSIS. Pakistan Business Review, 2017. 18(4): p. 924-942.

15. Soomro, Y.A., Antecedents of brand loyalty in the fashion industry of Pakistan: Moderating effect of Individual-level collectivist values. 2019.

16. Chou, C.-M., Social media characteristics, customer relationship and brand equity. American Journal of Business, 2019. 10(1).

17. Langaro, D., P. Rita, and M. de Fátima Salgueiro, Do social networking sites contribute for building brands? Evaluating the impact of users' 


\section{Three-Dimensional Brand Loyalty and Virtual Customer Relationships on Social Media-Based Brand Community}

participation on brand awareness and brand attitude. Journal of Marketing Communications, 2018. 24(2): p. 146-168.

18. Pinto, L., et al., Fostering Online Relationships With Brands Through Websites and Social Media Brand Pages. Journal of Promotion Management, 2019. 25(3): p. 379-393.

19. Back, K.-J., The effects of image congruence on customers' brand loyalty in the upper middle-class hotel industry. Journal of Hospitality \& Tourism Research, 2005. 29(4): p. 448-467.

20. Back, K.-J. and S.C. Parks, A brand loyalty model involving cognitive, affective, and conative brand loyalty and customer satisfaction. Journal of Hospitality \& Tourism Research, 2003. 27(4): p. 419-435.

21. Evanschitzky, H. and M. Wunderlich, An examination of moderator effects in the four-stage loyalty model. Journal of Service Research, 2006. 8(4): p. 330-345.

22. Lin, H.-H. and Y.-S. Wang, An examination of the determinants of customer loyalty in mobile commerce contexts. Information \& management, 2006. 43(3): p. 271-282.

23. Baumann, C., G. Elliott, and S. Burton, Modeling customer satisfaction and loyalty: survey data versus data mining. Journal of services marketing, 2012. 26(3): p. 148-157.

24. Oliver, R.L., Whence consumer loyalty? Journal of marketing, 1999. 63(4_suppl1): p. 33-44.

25. Omar, O. and S. Sawmong, Store Loyalty of the UK Retail Consumers. Journal of American Academy of Business, 2004.

26. Han, H. and K.-J. Back, Relationships among image congruence, consumption emotions, and customer loyalty in the lodging industry. Journal of Hospitality \& Tourism Research, 2008. 32(4): p. 467490.

27. Sicilia, M. and M. Palazón, Brand communities on the internet: A case study of Coca-Cola's Spanish virtual community. Corporate Communications: An International Journal, 2008. 13(3): p. 255-270.

28. Zhao, H., C. Su, and Z. Hua, To participate or not to participate in a brand micro-blog: Facilitators and inhibitors. Information Development, 2016. 32(5): p. 1774-1785.

29. Zhao, H., C. Su, and Z. Hua, Investigating continuance intention to follow a brand micro-blog: Perceived value and social identification. Information Development, 2016. 32(5): p. 14281441.

30. Chan, K.W., C.K. Yim, and S.S. Lam, Is customer participation in value creation a double-edged sword? Evidence from professional financial services across cultures. Journal of marketing, 2010. 74(3): p. 48-64.

31. Bilal, G., M.A. Ahmed, and M. Shehzad, Role of social media and social networks in consumer decision making: A case of the garment sector. International Journal of Multidisciplinary Sciences and Engineering, 2014. 5(3): p. 1-9

32. Rather, R.A., et al., Customer brand identification, affective commitment, customer satisfaction, and brand trust as antecedents of customer behavioral intention of loyalty: An empirical study in the hospitality sector. Journal of Global Scholars of Marketing Science, 2019. 29(2): p. 196-217.

33. Palmer, A.J., Relationship marketing: a universal paradigm or management fad? The learning organization, 1996. 3(3): p. 18-25.

34. Shahin Sharifi, S. and M. Rahim Esfidani, The impacts of relationship marketing on cognitive dissonance, satisfaction, and loyalty: the mediating role of trust and cognitive dissonance. International Journal of Retail \& Distribution Management, 2014. 42(6): p. 553-575.

35. Berry, S., No condition is permanent: The social dynamics of agrarian change in sub-Saharan Africa. 1993: University of Wisconsin Pres.

36. Möller, K. and A. Halinen, Relationship marketing theory: its roots and direction. Journal of marketing management, 2000. 16(1-3): p. 29-54.

37. Agariya, A.K. and D. Singh, What really defines relationship marketing? A review of definitions and general and sector-specific defining constructs. Journal of Relationship Marketing, 2011. 10(4): p. 203-237.

38. Kunz, W.H. and J. Hogreve, Toward a deeper understanding of service marketing: The past, the present, and the future. International Journal of Research in Marketing, 2011. 28(3): p. 231-247.

39. Morgan, R.M. and S.D. Hunt, The commitment-trust theory of relationship marketing. Journal of marketing, 1994. 58(3): p. 20-38.

40. Parasuraman, A. and L.L. Berry, Marketing services: competing through quality. New York, 1991.

41. Ali, M.N.M., Brand loyalty and relationship marketing in Islamic banking system. Canadian Social Science, 2010. 6(1): p. 25-32.
42. Payne, A. and P. Frow, A strategic framework for customer relationship management. Journal of marketing, 2005. 69(4): p. 167176.

43. Malhotra, N.K. and J. Agarwal, A stakeholder perspective on relationship marketing: framework and propositions. Journal of Relationship Marketing, 2002. 1(2): p. 3-37.

44. Oly Ndubisi, N., Relationship quality antecedents: the Malaysian retail banking perspective. International Journal of Quality \& Reliability Management, 2007. 24(8): p. 829-845.

45. Ndubisi, N.O., N.K. Malhotra, and C.K. Wah, Relationship marketing, customer satisfaction and loyalty: a theoretical and empirical analysis from an Asian perspective. Journal of International Consumer Marketing, 2008. 21(1): p. 5-16.

46. Sui, J.J. and S. Baloglu, The role of emotional commitment in relationship marketing: An empirical investigation of a loyalty model for casinos. Journal of Hospitality \& Tourism Research, 2003. 27(4): p. 470-489.

47. Muniz, A.M. and T.C. O'guinn, Brand community. Journal of consumer research, 2001. 27(4): p. 412-432.

48. Davis, R., I. Piven, and M. Breazeale, Conceptualizing the brand in social media community: The five sources model. Journal of retailing and consumer services, 2014. 21(4): p. 468-481.

49. Fournier, S. and J. Avery, The uninvited brand. Business horizons, 2011. 54(3): p. 193-207.

50. Laroche, M., M.R. Habibi, and M.-O. Richard, To be or not to be in social media: How brand loyalty is affected by social media? International Journal of Information Management, 2013. 33(1): p. 7682.

51. Habibi, M.R., Three essays on social media-based brand communities. 2015, Concordia University.

52. Judson, K.M., P.R. Devasagayam, and C.L. Buff, Self-perceived brand relevance of and satisfaction with social media. Marketing Management Journal, 2012. 22(2): p. 131-144.

53. Bagozzi, R.P. and U.M. Dholakia, Intentional social action in virtual communities. Journal of interactive marketing, 2002. 16(2): p. 2-21.

54. Brogi, S., Online brand communities: a literature review. ProcediaSocial and Behavioral Sciences, 2014. 109: p. 385-389.

55. Enginkaya, E. and H. Y1lmaz, What drives consumers to interact with brands through social media? A motivation scale development study. Procedia-Social and Behavioral Sciences, 2014. 148: p. 219 226.

56. Harris, L. and C. Dennis, Engaging customers on Facebook: Challenges for e-retailers. Journal of Consumer Behaviour, 2011 10(6): p. 338-346.

57. Coelho, P.S., P. Rita, and Z.R. Santos, On the relationship between consumer-brand identification, brand community, and brand loyalty. Journal of Retailing and Consumer Services, 2018. 43: p. 101-110.

58. Lipsman, A., et al., The power of "like": How brands reach (and influence) fans through social-media marketing. Journal of Advertising research, 2012. 52(1): p. 40-52.

59. Chintagunta, P., D.M. Hanssens, and J.R. Hauser, Marketing Science and Big Data. 2016.

60. Vohra, A. and N. Bhardwaj, From active participation to engagement in online communities: Analysing the mediating role of trust and commitment. Journal of Marketing Communications, 2017. 25(1): p. 89-114

61. Katz, M., R.M. Ward, and B. Heere, Explaining attendance through the brand community triad: Integrating network theory and team identification. Sport Management Review, 2018. 21(2): p. 176-188.

62. Woisetschläger, D.M., V. Hartleb, and M. Blut, How to make brand communities work: Antecedents and consequences of consumer participation. Journal of Relationship Marketing, 2008. 7(3): p. 237-256.

63. Preece, J., Online communities: designing usability, supporting sociability. Industrial Management \& Data Systems, 2000. 100(9): p. 459-460.

64. Fournier, S. and L. Lee, Getting brand communities right. Harvard business review, 2009. 87(4): p. 105-111.

65. Madupu, V. and D.O. Cooley, Antecedents and consequences of online brand community participation: a conceptual framework. Journal of Internet Commerce, 2010. 9(2): p. 127-147.

66. Jiao, Y., et al., Social value, content value, and brand equity in social media brand communities: A comparison of Chinese and US consumers. International Marketing Review, 2018. 35(1): p. 18-41.

67. Kaplan, A.M. and M. Haenlein, Users of the world, unite! The challenges and opportunities of Social Media. Business horizons, 2010. 53(1): p. 59-68.

68. Ouwersloot, H. and G. Odekerken-Schröder, Who's 
who in brand communities-and why? European Journal of Marketing, 2008. 42(5/6): p. 571-585.

69. Porter, C.E., et al., How to foster and sustain engagement in virtual communities. California management review, 2011. 53(4): p. 80110 .

70. Dholakia, U.M., R.P. Bagozzi, and L.K. Pearo, A social influence model of consumer participation in network-and small-group-based virtual communities. International journal of research in marketing, 2004. 21(3): p. 241-263.

71. Alexander Hars, S.O., Working for free? Motivations for participating in open-source projects. International Journal of Electronic Commerce, 2002. 6(3): p. 25-39.

72. McKenna, K.Y. and J.A. Bargh, Causes and consequences of social interaction on the Internet: A conceptual framework. Media psychology, 1999. 1(3): p. 249-269.

73. Nambisan, S. and R.A. Baron, Virtual customer environments: testing a model of voluntary participation in value co-creation activities. Journal of product innovation management, 2009. 26(4): p. 388-406.

74. Tsai, H.-T., H.-C. Huang, and Y.-L. Chiu, Brand community participation in Taiwan: Examining the roles of individual-, group-, and relationship-level antecedents. Journal of Business Research, 2012. 65(5): p. 676-684.

75. Bagozzi, R.P. and U.M. Dholakia, Antecedents and purchase consequences of customer participation in small group brand communities. International Journal of research in Marketing, 2006. 23(1): p. 45-61.

76. Erdoğmuş, İ.E. and M. Cicek, The impact of social media marketing on brand loyalty. Procedia-Social and Behavioral Sciences, 2012. 58: p. 1353-1360.

77. Russell-Bennett, R., C.E. Härtel, and S. Worthington, Exploring a functional approach to attitudinal brand loyalty. Australasian Marketing Journal (AMJ), 2013. 21(1): p. 43-51.

78. Lazarevic, V., Encouraging brand loyalty in fickle generation $Y$ consumers. Young consumers, 2012. 13(1): p. 45-61.

79. Keller, K.L. and D.R. Lehmann, Brands and branding: Research findings and future priorities. Marketing science, 2006. 25(6): p. 740-759.

80. Runyan, R.C. and C. Droge, A categorization of small retailer research streams: what does it portend for future research? Journal of Retailing, 2008. 84(1): p. 77-94

81. Rosenberg, L.J. and J.A. Czepiel, A marketing approach for customer retention. Journal of consumer marketing, 1984. 1(2): p. 45-51

82. Krishnamurthi, L. and S.P. Raj, An empirical analysis of the relationship between brand loyalty and consumer price elasticity. Marketing Science, 1991. 10(2): p. 172-183.

83. Aaker, D.A. and M.B. Equity, Capitalizing on the Value of a Brand Name. New York, 1991. 28: p. 35-37.

84. Casaló, L., C. Flavián, and M. Guinalíu, The impact of participation in virtual brand communities on consumer trust and loyalty: The case of free software. Online information review, 2007. 31(6): p. 775-792.

85. Tabaku, E. and E. Kushi, Service quality, customer Satisfaction, perceived value and brand Loyalty: a critical review of the literature. Academic Journal of Interdisciplinary Studies, 2013. 2(9): p. 223.

86. Kuikka, A. and T. Laukkanen, Brand loyalty and the role of hedonic value. Journal of Product \& Brand Management, 2012. 21(7): p. 529-537.

87. Vitez, O., What is the importance of brand loyalty. Retrieved from wisegeek: website: http://www. wisegeek. com/what-is-theimportance-of-brand-loyalty. htm, 2013.

88. Altaf, M., et al., STUDYING BRAND LOYALTY IN THE COSMETICS INDUSTRY. LogForum, 2012. 4(8).

89. Homburg, C. and A. Giering, Personal characteristics as moderators of the relationship between customer satisfaction and loyalty-an empirical analysis. Psychology \& Marketing, 2001. 18(1): p. 43-66.

90. Yang, Z. and R.T. Peterson, Customer perceived value, satisfaction, and loyalty: The role of switching costs. Psychology \& Marketing, 2004. 21(10): p. 799-822.

91. Kim, W.G., B. Jin-Sun, and H.J. Kim, Multidimensional customerbased brand equity and its consequences in midpriced hotels. Journal of Hospitality \& Tourism Research, 2008. 32(2): p. 235254.

92. Lee, Y.-K., K.-J. Back, and J.-Y. Kim, Family restaurant brand personality and its impact on customer's emotion, satisfaction, and brand loyalty. Journal of hospitality \& tourism research, 2009. 33(3): p. 305-328.

93. Chahal, H. and M. Bala, Confirmatory study on brand equity and brand loyalty: a special look at the impact of attitudinal and behavioural loyalty. Vision, 2010. 14(1-2): p. 1-12.

94. Yu, Y.-T. and A. Dean, The contribution of emotional satisfaction to consumer loyalty. International journal of service industry management, 2001. 12(3): p. 234-250.

95. TaghiPourian, M.J. and M.M. Bakhsh, Loyalty: From single-stage loyalty to four-stage loyalty. International Journal of New Technology and Research, 2015. 1(6).

96. Worthington, S., R. Russell-Bennett, and C. Härtel, A tridimensional approach for auditing brand loyalty. Journal of Brand Management, 2009. 17(4): p. 243-253.

97. Clark, M., H.G. Black, and K. Judson, Brand community integration and satisfaction with social media sites: a comparative study. Journal of Research in Interactive Marketing, 2017. 11(1): p. 39-55.

98. Coelho, A., C. Bairrada, and F. Peres, Brand communities relational outcomes, through brand love. Journal of Product \& Brand Management, 2019.

99. Habibi, M.R., M. Laroche, and M.-O. Richard, Testing an extended model of consumer behavior in the context of social media-based brand communities. Computers in Human Behavior, 2016. 62: p. 292-302.

100. Zheng, X., et al., Building brand loyalty through user engagement in online brand communities in social networking sites. Information Technology \& People, 2015. 28(1): p. 90-106.

101. Stokburger-Sauer, N., Brand community: Drivers and outcomes Psychology \& Marketing, 2010. 27(4): p. 347-368.

102. Ashley, C. and T. Tuten, Creative strategies in social media marketing: An exploratory study of branded social content and consumer engagement. Psychology \& Marketing, 2015. 32(1): p. $15-27$

103. Bergami, M. and R.P. Bagozzi, Self-categorization, affective commitment and group self-esteem as distinct aspects of social identity in the organization. British Journal of Social Psychology, 2000. 39(4): p. 555-577.

104. Gruen, T.W., J.O. Summers, and F. Acito, Relationship marketing activities, commitment, and membership behaviors in professional associations. Journal of marketing, 2000. 64(3): p. 34-49.

105. McWilliam, G., Building stronger brands through online communities. MIT Sloan Management Review, 2000. 41(3): p. 43.

106. Julian, D.A., et al., Citizen participation-lessons from a local United Way planning process. Journal of the American planning association, 1997. 63(3): p. 345-355.

107. Loureiro, S.M.C., A.R. Pires, and H.R. Kaufmann, Creating value for customers through engagement and participation in brand communities. International Journal of Business Performance Management, 2015. 16(2/3): p. 114-132.

108. Koh, J. and Y.-G. Kim, Knowledge sharing in virtual communities: an e-business perspective. Expert systems with applications, 2004. 26(2): p. 155-166.

109. Ranjan, K.R. and S. Read, Value co-creation: concept and measurement. Journal of the Academy of Marketing Science, 2016. 44(3): p. 290-315.

110. Kamboj, S. and Z. Rahman, The influence of user participation in social media-based brand communities on brand loyalty: age and gender as moderators. Journal of Brand Management, 2016. 23(6): p. 679-700.

111. Shang, R.-A., Y.-C. Chen, and H.-J. Liao, The value of participation in virtual consumer communities on brand loyalty. Internet research, 2006. 16(4): p. 398-418.

\section{AUTHOR PROFILE}

Author-1 Photo

Author-1 Photo
Ayesha Sharif, Ph.D. Scholar, Faculty of Azman Hashim International Business School (AHIBS), Universiti Teknologi Malaysia (UTM), 81310 Johor Bahru, Johor, Malaysia, ayeshasharif@yahoo.com

Dr.Zuraidah Binti Sulaiman, Senior Lecturer, Faculty of Azman Hashim International Business School (AHIBS), Universiti Teknologi Malaysia (UTM), 81310 Johor Bahru, Johor, Malaysia. 